\title{
Translating Political Speeches Using a Skopos - Theoretical Approach
}

\author{
OqabJabali* \\ Language Center Faculty of Humanities An-Najah National University, Nablus, Palestine
}

*Corresponding Author: OqabJabali, Language Center Faculty of Humanities An-Najah National University, Nablus, Palestine

\begin{abstract}
This study aims to examine thoroughly the translation of a specific kind of political discourse, namely political speeches. The translation of political texts (e.g., Abbas'speech at the UN 2012) is becoming more and more important and is an authoritative source for international community to understand the rights and interests of the Palestinians. By applying a skopos-theoretical approach, and identifying the micro-and macro-strategies used in translations of political speeches, the researcher seeks to answer the question of how political speeches are translated. In other words, what translation strategies are used to translate political texts? The study is meant to determine, using a descriptive-analytical approach, whether there appears to be a general strategic approach to translations of political speeches that highlight people's rights and reduce clash of civilizations. The study results show there are no ready-made strategies for translating political speeches, since translation is not only a technical process that uses translation procedures and applies transfer operations, but also a matter of understanding cultural, historical and political situations and their significance. The researcher recommends using some micro and macro strategies to render the text and maintain its impact on the target readership.
\end{abstract}

Keywords: Arabic translation, macro-strategies, micro-strategies, political speeches, skopos theory

\section{INTRODUCTION}

The world today is characterized by universal communication where people use the modern technology to communicate with each other. The media, the press, radio, television, cinema and, above all, the internet, help transfer preferred notions and ideas from one place to another. Communication is, thus, so global that local communication may turn to be international unconsciously as in the case of the Palestinian-Israeli conflict especially Abbas' speeches regarding the Palestinian membership of the UN. The Palestinian president is highly eloquent and his speeches are rhetorical mainly the one delivered in the $67^{\text {th }}$ UN General Assembly Session at the end of 2012 in which he strived to highlight the Palestinian national identity. The researcher wonders how translators would convert such a speech from Arabic into other languages namely English. Personally speaking, the first thought was to consider the semantic content not the stylistic features or the other way round. Then, the researcher made his mind to look deeply into the topic of translating political discourse, or how translators had approached that speech for practical considerations, i.e. translation is needed to achieve a real communicative impact, rather than for the purpose of learning Arabic. Social values are, to a large extent, depicted by people, media influence and its specific use especially if it is related to national sovereignty as well as national identity.

According to Kirkpatrick (2005), a leading role of language is to provide identity. National identity may be defined as a set of beliefs, conventions, traditions and practices shared by a group of people called nation, and differentiated from other groups. Hall (1992) argues that:

"National identity, like other identities, is about using resources of history, language and culture in the process of becoming rather than being: not "who we are" or "where we came from", so much as "what we might become". Thus national identity is in reality "cross-cut" by deep internal division's differences, and "unified" only though the exercise of different forms of cultural power (p. 276). 
According to Fairclough (1992), discourse as a social practice shapes and is shaped by the world around us. He believes that ideology is located in the structure of discourse, or what he refers to as 'order of discourse', meaning that ideology can be linked to past and present events. Ideology, however, does not only constitute part of the 'order of discourse', but it can also be present in the form and structure of the text. Discourse can, at times, be 'ideologically invested' (Fairclough 1992: 89). This means that both the structure of sentences and the components constituting them can be packed with ideological meaning (Shunnaq, 2000). Language as a social practice can be manipulated to express the speaker's or writer's own beliefs and ideologies. Such ideologies find their way into the text through the way sentences are structured and words are selected (Zunpik, 1994; Lahlali, 2012). Since ideologies are constructions of social relations and social identities, this paper examines how a translated language shapes and is shaped by ideologies.

It has been stated that translation studies are deeply related to the socio-political as well as sociocultural factors and consequently, the political discourse depends greatly on the act of translation in the sense that the linguistic abilities and behavior affect the political tendencies and or behavior of the polotologists. Trosborg (2000) argues that "international politics involves extensive translation" (p 188). Accordingly, translators play a vital role in political activities and arenas by making the job of international agencies and institutions, like the UN for example, much easier.

\section{Purpose OF The STUdy}

The general purpose of the study is to decide whether there is an inclination, from the translator's side, to focus on the content or the function. In other words, the researcher attempts to see if the translator tries to reproduce the content or the message of president's speech or to highlight the impact of that speech. Put simply, the translator tries to find out whether the translator is trying to translate the ST as it is or manipulate the ST in a way that paves the way to influence the readership or the listener in order to help them sympathize with speaker/orator and eventually vote for his appeal.

This study is meant, first, to investigate the definitions of relevant terminology (e.g., what is a text? what is text type? and what is political discourse and how is it different from other discourses?) in an attempt to discover a model that serves a two-fold purpose; on the one hand, it can be utilized in describing and classifying text types for the sake of interpretation and translation; and on the other hand, it may be used in identifying cultural differences and identity elements that are highlighted in the President's speech.

Furthermore, the researcher tends also to find out an exact definition of translation, that suits the aim of the study as the concept is defined differently by scholars, as well as related theories with much emphasis on skopos theory which is so crucial to the current study in the sense that it contains not only a theoretical perspective but also a pragmatic one. The theory also takes cultural differences into consideration. Finally, the researcher intends to hold a short comparison between the ST and the target, translated, text (in terms of length, paragraphing, and language formality) depending on the above mentioned model. The researcher seeks to answer the main problem of the study, i.e. how do translators manage political discourses? In other words, how are political speeches translated? Or what translation strategies are used to translate political texts?

Skopos theory is normally adopted in such cases especially because it looks at both theoretical aspects of the process of translation and pragmatic ones. In such a theory, translation is seen as an "act of intercultural communication, thus considering cultural differences in relation to translation." (Hansen, 2010, p 5). As a result, the main thesis of this study might be sorted as empirical and exploratory. It is empirical because it depends on authentic text that is translated under the auspices of the UN; it is also exploratory in the sense that it will show whether there is a given approach that can be applied to deal with political discourse. Some conceptual aspects will also be incorporated when related terms and genres are defined for the purpose of translation.

\subsection{Data}

The study is based on one real-life, authentic example of political discourse in the form of a speech delivered by the Palestinian President, Mahmoud Abbas, at the UN general Assembly trying to convey the Palestinian point of view regarding joining the UN as a non-member observer state, and the translation of that speech. The text as well as its translation is taken from the internet at different 
websites especially the Palestinian Ministry of Foreign Affairs. Abbas' speech will be referred to as the source text (ST), and its English equivalent as the target text (TT).

\subsection{Basic Terminology}

The use of the ST refers, basically, to the political speech upon which the whole paper depends; the TT refers to the outcome of the translation process, i.e. it is the English translation of the speech.

\subsection{Limitation of the Study}

The study aims at analyzing one and only one political speech due to its vast importance as an endeavor to get recognition from the General Assembly of the Palestinian national identity and an endeavor to change the status of Palestine.

\subsection{What is politics and political discourse?}

Human beings are described by prominent figures, Aristotle for instance, as political, in the sense that they form coalitions or groups; and social animals that live in groups within the limits of a state. Therefore, any kind of human society depends on interaction and mutual relationships; it depends on their ability to communicate. On the other hand, politics has something to do with power and in this domain Chilton (2004) states that

On the one hand, politics is viewed as a struggle for power, between those who seek to assert and maintain their power and those who seek to resist it. [...] On the other hand, politics is viewed as cooperation, as the practices and institutions that a society has for resolving clashes of interest over money, influence, liberty, and the like. (p. 3)

According to the above definition, politics cannot be carried out without a code because human interaction requires a language and that linguistic discourse is directly contained in and shaped by socio-cultural, ideological, and historical surroundings. Political discourse and/or text is seen as political interaction using a language in different manifestations either inside the country itself or among different countries. Thus, Schaffner (1997) argues that political discourse and political language includes speeches, treaties, press conferences, statements, editorials and commentaries in newspapers, etc. But what distinguishes a political text from any other text is that the former depends on thematic and functional considerations; it is a manifestation of political activities that serve a function or a number of functions. It is also directed to a larger public as it is cultural bound. Furthermore, political discourse/text reflects the speaker's ideology through the words used. For this reason, Politicians tend to use vague terms and expressions as they do not want to offend others, namely in international arenas such as the UN General Assembly forum. This is so clear when the Palestinian president used terms like (annexation Wall, isolating Israel or de-legitimizing it, bridges of dialogue instead of checkpoints and walls, etc.) to describe the Israeli political practices, politicians and /or institutions. Finally, the political text stresses on certain elements such as using kind of ritual forms to address the audience especially in international arenas. Mahmoud Abbas proves to be professional simply because he is always eloquent and speaking in Arabic, a language that bounds with, euphemisms, metaphors and similes. He uses (Mr. President of the General Assembly of the United Nations, Mr. Secretary-General of the United Nations, Excellences and Ladies and Gentlemen) very often in his speech to address the audience.

As far as political speeches are concerned, they are normally directed to a general audience. Abbas's speech is, directly, addressed to those who were attending the meetings of the UN General Assembly, and, indirectly, to the whole world. Such a speech is not merely directed to the Palestinian or Arab nation, but also includes the wider public in the rest of the world due to the importance of Palestine independence to the region as well as the entire world. If the Middle East conflict is resolved, a lot of things, on the ground, will change regionally, and globally. Political speeches are also delivered to express the speaker's point of view as well as those whom s/he represents. Abbas's speech is meant to expose the Palestinians' endeavors to attain an international consensus to admit their rights to join the UN as a member state. Political texts are seen as a language used by politicians in political situations or activities and the speakers exercise and manifest the power they have, in some way, through that language.

Shaffner (1997) distinguishes between two types of political speeches depending on the relationship between the speaker and the listener. The first category entails having a politician speaking to 
politicians; this kind of text is normally informative and communicative. The other type represents a politician who addresses not politicians; rather s/he addresses the wider public. Normally, these texts tend to be persuasive and are published in the media. The text, under scrutiny, exemplifies the first category as the Palestinian president was addressing his counterparts or those politicians who represent them.

\subsection{What is translation?}

It is beyond the scope of this study to go into the depths of the concept of translation. But to put it plainly, translation involves a translator who changes a ST into a target one. Therefore, it can be classified into three types according to Jakobson (1959) when he clarifies that:

"We distinguish three ways of interpreting a verbal sign: it may be translated into other signs of the same language, into another language, or into another, nonverbal system of symbols. These three kinds of translation are to be differently labeled:

Intralingual translation or rewording is an interpretation of verbal signs by means of other signs of the same language.

Interlingual translation or translation proper is an interpretation of verbal signs by means of some other language.

Intersemiotic translation or transmutation is an interpretation of verbal signs by means of signs of nonverbal sign systems." $\quad$ (p. 3)

\subsubsection{Different approaches of translation}

Despite the fact that translation studies, as an academic discipline, is relatively new, there have been a set of various theoretical approaches to translation. In the past, some theoreticians adopted the literal or word for word translation approach while others presented the free approach which results in a TT which is both "creative and aesthetically pleasing", Munday (2001). But recently, other approaches have been introduced.

In 1950s and 1960s, for example, there was the concept of equivalence which was adopted by Jakobson, EugineNida, Peter Newmark, Catford, and others. Nida (1969) provides a descriptive approach to the translation process focusing on the target reader and his/her reaction. Nida focuses on the equivalence whether it is formal or dynamic. For Catford (1995), translation is "the replacement of textual material in one language; source language (SL) by equivalent textual material in another language; target language (TL)" (p. 20). According to Newmark (1991) "translation is rendering the meaning of a text into another language in the way that the author intended the text"(p. 7).

Another modern approach is the functional or the skopos theory which shifts the focus from the word or sentence level to the text level keeping equivalence but at text as a whole rather than at words or even sentences. The core of this theory, which was introduced by Hans J. Vermeer in 1978, is the fact that knowing the intended purpose of the TT and the function of translation is important as it determines the translation method and that adequacy dominates equivalence.

A third approach is the communicative approach of translation which was introduced by Ian Mason, Andre Lefevre and Basil Hatim who contend that non-verbal meaning can be transferred and that cultural aspects of one language can be conveyed to another language through translation. Another closely related approach of translation is the one suggested by Lawrence Venuti who stresses the role of the translator on aspects relating to culture and politics. This approach stresses visibility whether of the translator or the translation itself. One additional approach is the interdisciplinary approach that combines the different approaches (e.g., literal, free, cultural, etc.) together in one comprehensive approach (Munday, 2001).

It can be understood from the previous part that there are different tendencies of approaching a text; some focus on certain aspects while others focus on totally different ones. Yet, among these approaches, skopos theory is deemed relevant as it adheres to the functional aspect of the translation process.

\subsection{What is Skopos Theory?}

The word skopos means purpose. Any kind of translational act, even translation itself, might be considered or seen as a "purposeful activity" Nord (1997). Here the TT as well as the translation 
strategies and methods the translator adopts, should be determined by the purpose that the TT is meant to achieve in the target context; that is, "the end justifies the means" (Reiss \& Vermeer 1984, p. 101).

According to this theory, any act of translation entails a commission and is done according to a skopos, which is normally determined by the translator or those whom he represents. The purpose of the TT and the mode in which it is to be realized are decided by the commissioner and the translator. The translator is responsible for the translation outcome, Vermeer (2000).

Translation is, in fact, the result of a functionally suitable TT based on a ST. Vermeer defines the skopos theory as follows (cited and translated by Nord, 1997):

Each text is produced for a given purpose and should serve this purpose. The skopos rule thus reads as follows: translate/interpret/speak/write in a way that enables your text/translation to function in the situation it is used and with the people who want to use it and precisely in the way they want it to function (p. 29).

The core of this theory goes around the fact that translation should always be carried out to achieve the goal of the TT in the target language situation (Nord, 2007). It also focuses on the pragmatic part of translation. The theory has many aspects but, for the sake of brevity, the researcher meant to shed light on the most relevant ones.

To begin with, the translator, here, is a professional participant who does the translation for market considerations; s/he carries out tasks given by an authority. This means that the translation process is done in lieu with the purpose of the TT (Schjoldager, 2008) and the translator might be invisible. Consequently, the translator can select whether to be source-text oriented or target-text oriented. The translator is not only an expert of the ST but he is also the TT ultimate producer who is straightforwardly responsible for the translation, (Vermeer, 2000:231).

The skopos theory determines the important factors in the translation process. As noted above, the purpose of TT determines the translation techniques and strategies, but "one of the most important factors determining the purpose of a translation is the addressee" (Nord, 1997, p. 12). In other words, when the target readers are chosen and specified, the intention of the translation process can automatically be specified. The skopos/purpose of the translation of the speech of Mahmoud Abbas is to provide information about the Palestinian case and the Palestinian sufferings (informative) and to promote the Palestinian image and fate (operative).

Second, skopos theory recognizes translation as an act of communication. Therefore, some translation problems might appear especially if the ST bounds with cultural elements and the two languages belong to two different cultures which is the case of the speech under scrutiny.

Third, the skopos theory considerably depends on the significance of the translation audience and the vital role they play. Vermeer (2000) postulates that "Every translation presupposes a commission which should explicitly or implicitly contain a statement of skopos in order to be carried out at all" (p. 228). Consequently, Abbas' speech cannot be translated, at the UN, without an authorization.

Finally, the skopos theory requires and demands a process of redefining the relationship between the ST and the target one. The political discourse is content based rather than form based although some might be both. Therefore, the translator must strive to render the ST conceptual content and is not entitled to maintain its linguistic form or style.

\section{ANALYSES}

The ST is Mahmoud Abbas's speech, which he delivered during the proceedings of the UN General Assembly on November 29, 2012 in an attempt to appeal all nations to vote for Palestine to be a nonobserver member state at the UN. This speech is very important as it culminates the Palestinians' efforts to gain recognition from the UN and then independence in the near future; it marks Palestine's transition from an observer to a member state. Its real intention is to persuade all $\mathrm{UN}$ members to vote for Palestine; its purpose is to convince the addressees to support the addresser.

Although the text is overall persuasive and conative, there are multiple functions as well. The beginning and end are phatic as they signal the outset and the end of the speech. The text is also poetic as it abounds with rhetorical figures; it is also emotive expressing the speaker's opinion as well as his entire nation's opinion. 
With respect to the tenor of speech, the speaker is a professional politician addressing his counterparts not only in the meeting but also everywhere using formal language. This is clear in the titles used to address the audience and the very polite expressions. The text is full of the first person plural pronoun "WE" which refers to the president and his people. Considering the field and mode of the topic, it is a spoken political text in almost all aspects especially because it is prepared in advanced.

The typical features of political texts include, to mention some, the following. Firstly, as a political spoken genre, the speech was delivered face-to-face to almost similar counterparts; most of the addresses were presidents, ministers or other high ranking officials representing their countries. Secondly, it contains a lot of cultural elements, terminologies and expressions, e.g. Palestine Liberation Organization (PLO), Palestine, Gaza Strip, Al-Nakba of 1948, etc, that could pose translation problems, should the translator failed to understand them. Thirdly, the speech has a lot of rhetorical elements, especially metaphors such as "Israeli bombs on the Gaza Strip, wiping out entire families, their men, women and children murdered along with their dreams, their hopes, their future...", "the United Nations as a beacon of hope", "The rope of patience is shortening and hope is withering.", etc. ; these element could also cause some difficulties as well. There are also examples of alliteration and assonance when the president said "We have heard and you too have heard"; hyperbole in "The Palestinian people, who miraculously recovered from the ashes of Al-Nakba of 1948 ..."; there are plenty of antitheses like "the injustice and for achieving justice", "And, they will end the division and strengthen their national unity."

The translation used in this study is that which was published online by Voice of America. This translation was carried out at the UN General Assembly and after being compared to other translations in different website, the researcher, who is a translator himself, has noticed that all translations are almost the same. Yet, it is not known, to the researcher, who did the translation. The real intention of the translation is to make it easier for non-Arab listeners to understand the speaker and then vote for, vote against or even abstain. When comparing the ST to the TT, the researcher found the ST is made of 26 segments or paragraphs while the TT contains 30 segments.

In the final analysis the translation is compared to the ST, based on the model of analysis mentioned above. The analysis indicates a clear pattern in macro strategies as well as micro strategies of translation. According to Schjoldager (2008), there are two types of macro strategy translation: source-text oriented and target-text oriented. The speech under scrutiny has been translated following a source-text oriented macro strategy as it focused on the ST form and content; it is a communication of somebody else's speech and it is, indeed, an overt translation rather than a covert one. Micro strategies, on the other hand, deal with solving translation problems that might encounter the translator both at word and sentence level. Despite the fact that professional translators employ these strategies intuitively, they help making the specific choices with respect to the translation (p. 89).

There are many types of micro strategies outlined by Schjoldager (2008) and Cintaz (2008). The researcher has made his mind to adopt Schjoldager's micro strategies (as they fit these types of texts i.e., political texts) rather than those suggested by Cintaz which suit different types of texts mainly subtitling and humorous texts. Schjoldager's micro strategies include direct transfer, calque, direct translation, explicitation, word for word, change of structure, adaptation, addition, substitution, deletion, loan translation and others (Schjoldager 2008, p. 92).

For a detailed presentation of the various micro strategies used, the researcher has decided to give examples, from both the source text and the target text, of the most prominent strategies used by the translators.

\subsection{Direct transfer}

To start with, the translator uses direct transfer which is known to many theoretists as loan translation where the ST word is rendered into the TT as it is because the two languages use the same word like (Palestine, Israel, al-Nakba, etc.).

Table1. The direct transfer translating strategy

\begin{tabular}{|c|c|c|}
\hline Micro strategy & The Source Text (Arabic) & The Target Text (English) \\
\hline \multirow[t]{2}{*}{ Direct transfer } & تجيء فلسطين اليوم إلى الجمعية العامة للأمم المتحدة & $\begin{array}{l}\text { Palestine comes today to the United } \\
\text { Nations General Assembly }\end{array}$ \\
\hline & ضحايا العدو ان الإسر ائيلي & victim to the latest Israeli aggression \\
\hline
\end{tabular}




\begin{tabular}{|c|c|c|}
\hline & لقد اجترح الثعب الفلسطيني معجزة النهوض من رماد العام 1948 النكبة 1948 & $\begin{array}{l}\text { who miraculously recovered from the ashes } \\
\text { of A1-Nakba of } 1948\end{array}$ \\
\hline
\end{tabular}

\section{Calque}

When using calque, a translator has two choices. The first choice is to transfer the structure of an item in the source text to the target text. The second choice is to make a very close translation of the source-text item. The result of the two choices is an unidiomatic target-text item.

Table2. Calque translating strategy

\begin{tabular}{|c|c|c|}
\hline Micro strategy & The Source Text (Arabic) & The Target Text (English) \\
\hline \multirow[t]{4}{*}{ Calque } & مسائرضولياتها على الأسرة الدولية الفلسطيني ونحو السلام. & $\begin{array}{l}\text { which in turn obliges the international community } \\
\text { to shoulder its responsibilities towards the } \\
\text { Palestinian people and towards peace. }\end{array}$ \\
\hline & و الآمال تذوي & and hope is withering \\
\hline & وشعبنا متمسك بحقه في الدفاع عن نفسه & $\begin{array}{l}\text { And our people cling to the right to defend } \\
\text { themselves }\end{array}$ \\
\hline & 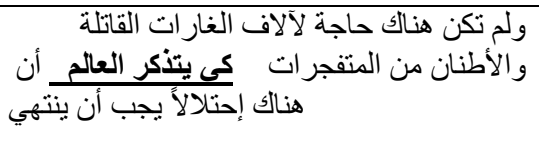 & $\begin{array}{l}\text { There was no need for thousands of deadly raids } \\
\text { and tons of explosives for the world to be } \\
\text { reminded that there is an occupation that must } \\
\text { come to an end }\end{array}$ \\
\hline
\end{tabular}

In the first example, the translator chose to use the verb (shoulder) to render the Arabic equivalent (الاضطلاع) in a completely different form. The researcher contends that the verb (undertake) is better than the verb shoulder because, according to Cambridge Dictionary, this verb (undertake) is used when someone gives someone else or a group of people complete support during difficult times, therefore; this verb is more idiomatic than shoulder. In the second example, the translators transferred the verb as a singular noun rather than plural as it is used in the ST. So, (الآمال) is translated as (hope) rather than (hopes). In the third example, again the translator rendered the adjective into a verb and, thus, lost some of the idiomatic aspect of adjectives. Adjectives are more emphatic than verbs. In the last example the translator used the passive structure rather than an active voice which is used in the ST.

\subsection{Direct Translation}

When using direct translation, the source text is translated using a so-called "word-for-word procedure". Often, this word-for-word procedure uses linguistic equivalents, which are supposed to cover all potential meaning of the source text. According to Schjoldager (2008), the result of direct translation is an idiomatic target text, i.e. a target text which uses the same language native speakers may use in similar situations.

Table3. The direct translation translating strategy

\begin{tabular}{|c|c|c|}
\hline Micro strategy & The Source Text (Arabic) & The Target Text (English) \\
\hline \multirow[t]{4}{*}{ Direct Translation } & 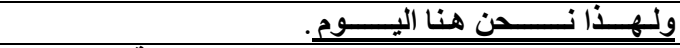 & This is why we are here today. \\
\hline & و والاعدد متطاءات و الاحتلات مصالحة تاريخية تطوي صفحة الحروب & $\begin{array}{l}\text { defined the requirements for a } \\
\text { historic reconciliation that would } \\
\text { turn the page on war, aggression } \\
\text { and occupation. }\end{array}$ \\
\hline & لم نسمع من أي مسؤول إسر ائيلي كلمة واحدةً & $\begin{array}{l}\text { We ave not heard one word from } \\
\text { any Israeli official }\end{array}$ \\
\hline & وحبل الصبر يقصر & The rope of patience is shortening \\
\hline
\end{tabular}

These four examples show that the translator opted for direct translation or word for word translation. (نطوي صفحة) should have been translated as stop rather than turn the page; and (حبلالصبر يقصر) is not used in the target language. The researcher has consulted many dictionaries including dictionaries of idioms but has not found anything.

\section{DeLETION}

Deletion entails dropping a unit of meaning from the source text in the target text. The text under scrutiny abounds with examples of deletions. For the sake of brevity, he researcher decides to include four examples only. The underlined words have been deleted completely. 
Table4. Deletion translating strategy

\begin{tabular}{|c|c|c|}
\hline Micro strategy & The Source Text (Arabic) & The Target Text (English) \\
\hline \multirow[t]{4}{*}{ Deletion } & 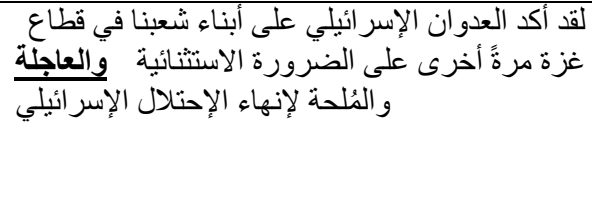 & $\begin{array}{l}\text { The Israeli aggression against our } \\
\text { people in the Gaza Strip has } \\
\text { confirmed once again the urgent and } \\
\text { pressing need to end the Israeli } \\
\text { occupation }\end{array}$ \\
\hline & 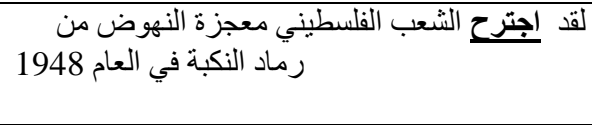 & $\begin{array}{l}\text { The Palestinian people, who } \\
\text { miraculously recovered from the } \\
\text { ashes of A1-Nakba of } 1948\end{array}$ \\
\hline & لتأكيد تماثلنا وتو افقنا مع الشر عية الدولية & $\begin{array}{l}\text { to confirm our adherence to } \\
\text { international legitimacy }\end{array}$ \\
\hline & ومو اقف وسطية تساوي بين الضحية و الجلاد. & $\begin{array}{l}\text { and by position that equate the } \\
\text { victim and the executioner. }\end{array}$ \\
\hline
\end{tabular}

\subsection{Addition}

Unlike deletion, when using addition, a unit of meaning which is not present in the source text is added intentionally to the target text by the translator (Schjoldager 2008).

Table5. Addition translating strategy

\begin{tabular}{|c|c|c|}
\hline Micro strategy & The Source Text (Arabic) & The Target Text (English) \\
\hline \multirow[t]{2}{*}{ Addition } & و عندما أقرق المجلس الوطني الفلسطيني عام 1988 مبلادرة الفلسطينية & $\begin{array}{l}\text { When the Palestine National Council } \\
\text { decided in } \mathbf{1 9 8 8} \text { to pursue the } \\
\text { Palestinian peace initiative }\end{array}$ \\
\hline & إن الجمعية العامة للأمم المتحدة مطالبة اليوم بإصدار. & $\begin{array}{l}\text { The General Assembly is called } \\
\text { upon today to issue a birth certificate } \\
\text { of the reality of the State of } \\
\text { Palestine. }\end{array}$ \\
\hline
\end{tabular}

In the above examples, the underlined words and expressions are not used in the source text. The first example is very straightforward; the translator should have rendered (أقر) as adopted rather than decided to pursue. In the second example, the underlined expression (i.e., of the reality) is extra.

\subsection{Adaptation}

Adaptation is a more creative micro strategy than other micro strategies (Schjoldager 2008). During this process, the effect of an item in the source text is recreated fully or partially in the target text. Adaptation is useful when the translator wants to copy the way the author of the source text was thinking; it is also useful when the translator wants to replace ST cultural references with TT cultural references in covert translations.

Table6. Adaptation translating strategy

\begin{tabular}{|c|c|c|}
\hline Micro strategy & The Source Text (Arabic) & The Target Text (English) \\
\hline \multirow[t]{2}{*}{ Adaptation } & وقذف بهم من كنف بلادهم الجميلة الناهضة إلى مخئين & $\begin{array}{l}\text { thrown from their beautiful, } \\
\text { embracing, prosperous country to } \\
\text { refugee camps }\end{array}$ \\
\hline & في تلك الأيام السوداء أخذ شعبنا يتطلع إلى الأمدة & $\begin{array}{l}\text { In those dark days, our people had } \\
\text { looked to the United Nations }\end{array}$ \\
\hline
\end{tabular}

In these two examples, adaptation was significantly used by the translator. The word (كنف) which can be translated as (bosom) was rendered in a more beautiful image using (embracing) which refers to the action that is done in one's bosom. In the second example, the translator used (had looked to) instead of looked at to render (يتطلع إلى ) from Arabic. Here, the translator changed the tense and used a more idiomatic phrasal verb (look to) instead of (look at) because this phrasal verb means go to someone hoping for someone to provide you with something such as help and guidance.

\subsection{Substitution}

Substitution is used to change the meaning of the source text in the target text. It is obvious that the item in the TT is a translation of an item from the ST, but the semantic meaning of the ST item has changed in the TT (Schjoldager 2008). 
Table7. Substitution translating strategy

\begin{tabular}{|c|c|c|}
\hline Micro strategy & The Source Text (Arabic) & The Target Text (English) \\
\hline \multirow[t]{3}{*}{ Substitution } & 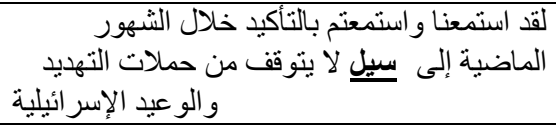 & $\begin{array}{l}\text { We have heard and you too have heard } \\
\text { specifically over the past months the } \\
\text { incessant flood of Israeli threats }\end{array}$ \\
\hline & إن ما يدفع الحكومة الإسر ائيلية إلى التمادي & $\begin{array}{l}\text { What permits the Israeli Government to } \\
\text { blatantly continue }\end{array}$ \\
\hline & لن نملّ ولن نكلّ ولن يفتُرَ تصميمنا & We will not give up, we will not tire \\
\hline
\end{tabular}

In the first example, the word (سيلي) has been replaced by (flood); it would be better if the translator used flow which is more useful. In the second example, the word (يدفيع) has been substituted by a completely irrelevant word that changes the purpose of the ST. The last example (نملِع), the phrasal verb (give up) does not fit; it changes the meaning completely. The verb (يمل)in Arabic means get bored rather than give up.

\subsection{Explicitation}

Explicitation is a micro strategy which makes implicit information in the source text explicit in the target text (Schjoldager 2008). One example has been found in the ST.

Table8. Explicitation translating strategy

\begin{tabular}{|c|c|c|}
\hline Micro strategy & The Source Text (Arabic) & The Target Text (English) \\
\hline Expl & الذي استند إلى القرار 181 الصادر عن هيئتكم: & $\begin{array}{l}\text { which was based on resolution } 181 \text { (II) ( } 29 \\
\text { November 1947), adopted by your august body }\end{array}$ \\
\hline
\end{tabular}

When you look at the ST, the date of Resolution 181 was not mentioned; it was implicit. However, the translator decided to make it explicit and provided it.

\subsection{Omission}

There are instances of omissions that are almost unavoidable due to time-and-space constraints, but the strategy is also applied if no equivalent term exists in the target language. The translator may choose to delete parts of the ST if he finds the segment unimportant or if the segment can be omitted without the general message is lost. There are two instances of omissions in this text. They might be forgotten unintentionally by the translator.

Table9. Omission translating strategy

\begin{tabular}{|c|c|c|}
\hline Micro strategy & The Source Text (Arabic) & The Target Text (English) \\
\hline \multirow[t]{2}{*}{ Omission } & 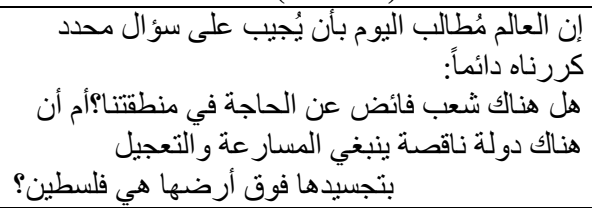 & No translation \\
\hline & 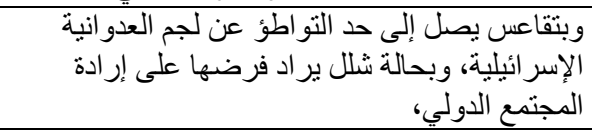 & No translation \\
\hline
\end{tabular}

\section{RESULTS AND DISCUSSION}

This study starts with the basic question of how to translate political discourse. However, the researcher decides to answer the question using skopos theory with much more emphasis on a tendency that goes around the ST. At first, the researcher provides an adequate definition of what political texts are and what are the main features of these texts. Furthermore, the researcher sheds some light on translation as a strategy and translation approaches used especially skopos theory.

The rhetorical elements, namely metaphors, are also rendered and reproduced properly and adequately in the translation as the text is political. Formality has also been maintained simply because the two languages are used in the United Nations proceedings and the ST is very formal. All of this lead to one further conclusion, i.e. there are no indications that the translation is adapted to English cultural conventions. Furthermore, the translator sticks to the ST at both word and sentence level; the translator has focused on the semantic equivalence as he is mainly interested in the real function of or purpose of translation. Finally, the translation is presented as documentation of the original United 
Nations speech which resulted in the acknowledgement of the Palestinian national identity and a change of Palestine status inside the UN. The text highlights the Palestinian people's rights and it may reduce clash of civilizations with the Jews.

However, the results cannot be taken to be general, but should more be taken as an indication due to the limited number of texts. Therefore, when political texts need to be translated using such a theoretical approach, skopos theory, translators are advised to follow a source-text oriented approach with some limitations.

\section{CONCLUSION}

The general purpose of the current study is to decide whether there is an inclination, from the translator's side, to reproduce the content or the message of president's speech or to highlight the impact of that speech; it also tries to find out whether the translator is trying to render the ST as it is or manipulate the ST in a way that paves the way to influence the readership or the listener in order to help them sympathize with speaker/orator and eventually vote for his appeal.

This study is meant to answer the main question of the study, i.e. how do translators manage political discourses? In other words, what translation strategies are used to translate political texts? The study results show that translating political speeches is not that easy and consequently there might be some kind of loss due to the fact that the main task of translators is to create a speech that contains the essence of the message that is included in the ST. Therefore, the translator is supposed understand not only the words, expressions and sentences and what they mean, but also what impact, be it political, historical, religious, the text has as the gist of Skopos theory suggests. Translators are also required to know how to maintain such an effect on the target reader. There are many techniques and strategies that translators may use achieve such a purpose. Some are micro and others are macro. Among the micro strategies the translator of the ST uses are direct transfer, direct translation, calque, substitution, addition, deletion, and others. In conclusion, the translator main mission is not to copy what is being said, but to put himself/herself in the original writer/speaker shoes and render the meanings.

\section{REFERENCES}

[1] Chilton, P. (2004). Analysing Political Discourse: Theory and Practice. London: Routledge

[2] Cintas, J. D. (2008). The Didactics of Audiovisual Translation. John Benjamin's Publishing Company: Amsterdam/Philadelphia

[3] Fairclough, N. (1992). Discourse and Text: Linguistic and Intertextual Analysis within Discourse Analysis. Discourse and Society, 3 (2): 193-217

[4] Hall, S. (1992). The Question of Cultural Identity. Modernity and Its Futures: Understanding Modern Societies. Cambridge, UK.

[5] Hansen, L. (2010). Translation of political speeches - A skopos-theoretical analysis. A Master Thesis: cand.ling.merc. Engelsk. - Translatør- ogTolkeprofil. Aarhus School of Business, Aarhus University. June 2010.

[6] Jakobson, R. (1959). "On Linguistic Aspects of Translation." in Venuti, Lawrence, ed. The Translation Studies Reader. London: Routledge, 2000, 113-118.

[7] Kirkpatrick, A. (2005). English across cultures: Identity and communication. In Honna, Nobuyki (Ed.), English as an international language (pp. 161-182). Tokyo JN: Aoyama Gakuin University

[8] Lahlali, M. (2012). 'Repetition and Ideology in Political Speeches'. Journal of Arab Media and Society. Issue 15

[9] Munday, J. (2001). Introducing Translation Studies: Theories and Applications. London: Routledge.

[10] Nord, C. (1991). "Scopos, loyalty and translational conventions." Target, 3 (1): 91-109.

[11] Nord, C. (1997). Translating as a Purposeful Activity: Functionalist Approaches Explained. Manchester: St. Jerome.

[12] Nord, C. (2007). Translation as a Purposeful Activity - Functionalist Approaches Explained. Manchester: St. Jerome Publishing.

[13] Newmark, P. (1991). About Translation: Multilingual Matters. Cleve don, Philadelphia, Adelaide: Multilingual Matters Ltd.

[14] Reiss, K. \& Hans J. Vermeer. (1984). GrundlegungeinerallgemeinenTranslationstheorie. Tübingen: Niemeyer. 
[15] Schaffner, C. (1997). Strategies of Translating Political Texts. In: Trosborg, Anne (ed.). 1997 Text Typology and Translation. John Benjamins Publishing Company, Amsterdam.

[16] Schjoldager, A. (2008). Understanding Translation. Arhus: Academica.

[17] Shunnaq, A. (2000). Arabic-English translation of political speeches. Perspectives, 8(3), $213-28$.

[18] Trosborg, A. (2000). Discourse analysis as part of translator training. Current Issues in Language \& Society, 7, 185-228.

[19] Vermeer, H. J. (2000). "Skopos and commission in translational action." A. Chesterman (trans.). In L. Venuti (ed.). The Translation Studies Reader. London: Routledge, 221-233.

[20] Zupnik, Y.-J. (1994). A pragmatic analysis of the use of person deixis in political discourse. Journal of Pragmatics, 21(4), 339-383.

\section{AUTHOR'S BIOGRAPHY}

DrOqabJabali, was the director of the Language Center and is now instructor of English in the Department of English at An-Najah National University, Nablus, Palestine. Besides teaching writing, translation and linguistic courses, he is a freelance translator and he teaches English for specific purpose in the language center. He holds a PhD in Cultural Studies and Political Sciences from the Jagiellonian University in Krakow, Poland, a Master's degree in Translation and Applied Linguistics, and a High Diploma in English teaching Methods, in addition to a BA in English Language and Literarture. His major publications include writing, translation and linguistic studies, education, medical education and women studies.

Citation: OqabJabali. "Translating Political Speeches Using a Skopos - Theoretical Approach" International Journal of Humanities Social Sciences and Education (IJHSSE), vol 8, no. 1, 2021, pp. 81-91. doi: https://doi.org/10.20431/2349-0381.0801010.

Copyright: (c) 2021 Authors. This is an open-access article distributed under the terms of the Creative Commons Attribution License, which permits unrestricted use, distribution, and reproduction in any medium, provided the original author and source are credited. 